\title{
Pemerolehan Ungkapan-Ungkapan Bahasa Arab Bagi Santriwati Baru di Pondok Pesantren Putri
}

\author{
Thoibatun Nafisah' ${ }^{1}$, Jasmani², Hamidah ${ }^{3}$ \\ ${ }^{1}$ Institut Agama Islam Negeri Palangka Raya \\ 2 Institut Agama Islam Negeri Palangka Raya \\ 3 Institut Agama Islam Negeri Palangka Raya \\ Corresponding E-mail: hamidah@iain-palangkaraya.ac.id
}

\begin{abstract}
In a female Islamic boarding school in South Kalimantan, Arabic and English are applied in daily communication, both in formal and informal settings. Seeing the efforts of both the Islamic boarding school and the students themselves in mastering Arabic including its expressions, this qualitative descriptive study was carried out with the aim of describing how the students' Arabic expressions were obtained and also the types of expressions, because each Islamic boarding school and even each individual and group had individual efforts to improve Arabic language skills. The results showed that the acquisition of Arabic expressions is obtained through listening to Arabic conversations both in formal and informal environments as well as through learning, both learning that has been determined by the Islamic boarding school such as memorizing the expressions on the media card, studying individually or studying in groups. The types of Arabic expressions obtained in the Islamic boarding school for girls are through listening and learning in the form of teachings, appeals and prohibitions. The implication of this research is that foreign language speaking skills will be easily mastered with a spirit of learning, learning strategies and the use of learning media.
\end{abstract}

Keywords: Female Islamic Boarding School; Expression

\begin{abstract}
Abstrak
Di sebuah pondok pesantren putri di Kalimantan Selatan diterapkan bahasa Arab dan bahasa Inggris dalam komunikasi sehari-hari, baik dalam lingkungan formal maupun informal. Melihat adanya upaya baik dari pihak pondok pesantren maupun santriwati sendiri dalam menguasai bahasa Arab termasuk ungkapannya, maka dilaksanakan penelitian deskriptif kualitatif ini dengan tujuan mendeskripsikan bagaimana pemerolehan ungkapan bahasa Arab santriwati dan juga jenis ungkapan tersebut, karena setiap pondok pesantren dan bahkan setiap individu dan kelompok memiliki upaya masing-masing untuk meningkatkan kemampuan berbahasa Arab. Hasil penelitian menunjukkan bahwa pemerolehan ungkapan bahasa Arab didapatkan melalui menyimak percakapan berbahasa Arab baik di lingkungan formal maupun informal serta melalui belajar, baik belajar yang sudah ditentukan oleh pondok pesantren seperti menghapal ungkapan yang ada di media kartu, belajar secara individu maupun belajar secara kelompok. Adapun jenis ungkapan bahasa Arab yang diperoleh di lingkungan pondok pesantren putri tersebut melalui menyimak dan belajar berupa ajaran, himbauan dan larangan. Implikasi dari penelitian ini adalah keterampilan berbicara bahasa asing akan mudah dikuasai dengan semangat belajar, strategi belajar dan penggunaan media pembelajaran.
\end{abstract}

Kata Kunci: Pondok Pesantren Putri; Ungkapan Bahasa Arab 


\section{PENDAHULUAN}

Bahasa adalah alat komunikasi manusia yang diperolehnya sejak lahir, yang digunakan dalam mengungkapkan pikiran dan perasan, serta dapat membangun kebudayaan dan menguasai ilmu pengetahuan dalam meningkatkan mutu kehidupannya (Devianty, 2017; Suardi, Ramadhan, \& Asri, 2019). Bahasa merupakan realitas yang tumbuh dan berkembang sesuai dengan tumbuh kembangnya manusia pengguna bahasa itu sendiri. Realitas bahasa di dalam kehidupan ini semakin menambah kekuatan eksistensi manusia sebagai makhluk yang berbudaya dan beragama (Hermawan, 2011).

Dalam kehidupan sehari-hari terdapat ungkapan-ungkapan bahasa yang lazim digunakan. Setiap bahasa memiliki ungkapan masing-masing. Setiap ungkapan dalam suatu bahasa tidak mesti harus sama terjemahannya sesuai dengan kosa kata bahasa tersebut seperti halnya kalimat biasa dalam bahasa lain, tetapi berupa kata-kata sebagai ungkapan yang sudah lazim digunakan oleh penuturnya.

Penguasaan sebuah bahasa oleh seorang anak dimulai dengan perolehan bahasa pertama. Pemerolehan bahasa atau akuisisi bahasa adalah proses yang berlangsung di dalam otak anak-anak ketika dia memperoleh bahasa pertamanya. Tahap pemerolehan bahasa pertama dibagi menjadi empat tahap, yaitu tahap pemerolehan kompetensi dan performansi, tahap pemerolehan semantik, tahap pemerolehan sintaksis dan tahap pemerolehan fonologi (Suardi et al., 2019). Pemerolehan bahasa dipengaruhi oleh beberapa faktor antara lain orangtua dan keluarga, lingkungan dan kemampuan idividu si anak (Sentosa \& Apriliani, 2020). Proses pemerolehan bahasa merupakan salah satu aspek akulturasi juga suatu tingkat pengakulturasian seseorang terhadap kelompok bahasa tertentu dalam proses memperoleh bahasa lainnya atau yang dimaksud bahasa kedua atau bahasa asing (Tarigan, 2011).

Bahasa diajarkan dengan tujuan agar siswa memiliki kompetensi berkomunikasi dengan menggunakan bahasa yang dipelajarinya dalam berbagai situasi sosial dan fungsional (Muradi, 2014). Salah satu bahasa asing yang diajarkan di madrasah, pondok pesantren dan perguruan tinggi Islam dan lainnya di Indonesia adalah bahasa Arab. Bahasa Arab merupakan bahasa yang setidaknya harus dipahami seorang muslim dalam melaksanakan ibadah khususnya shalat (Hamidah, 2019). Seiring kebutuhan komunikasi, model pembelajaran dan pemerolehan 
bahasa kedua atau asing lebih menekankan pada output bahasa (Sundari, 2017). Rekonstruksi pembelajaran bahasa Arab dilakukan dalam upaya melestarikan pengetahuan bahasa Arab sebagai alat untuk memahami pengetahuan keislaman bagi siswa. Salah satunya adalah dengan menciptakan lingkungan berbahasa (Hidayat, 2012; Vetiana, 2019).

Lingkungan bahasa adalah situasi suatu wilayah tertentu di mana suatu bahasa itu tumbuh dan berkembang dan digunakan oleh penuturnya mencakup segala hal yang didengar dan dilihat siswa kaitannya dengan bahasa kedua yang sedang dipelajarinya, dan mempengaruhi proses komunikasi berbahasa. Lingkungan bahasa tersebut berbentuk formal atau informal yang keduanya berperan dalam proses pemerolehan bahasa (Purba, 2013; Unsi, 2015). Lingkungan pembelajaran bahasa formal sengaja diciptakan dan terprogram untuk mencapai tujuan pembelajaran yang diharapkan dan memotivasi siswa untuk selalu berkomunikasi dengan menggunakan bahasa Arab pada suatu lingkungan dalam kehidupan sehari-hari (Davik, 2019). Lingkungan bahasa`informal berperan terutama lingkungan siswa sebaya dan lingkungan informal lainnya seperti lingkungan bahasa pengajar (Purba, 2013).

Faktor lingkungan bahasa berperan dalam keberhasilan pembelajaran bahasa terutama kemampuan berbicara, sehingga penciptaan lingkungan bahasa menjadi suatu program yang sangat penting. Lingkungan bahasa tercipta dari dukungan pihak yang memiliki perhatian dan juga dukungan berupa sarana serta dukungan tenaga ahli (Unsi, 2015). Pada umumnya pelajar memiliki persepsi baik terhadap lingkungan belajar bahasa yang dikembangkan oleh asrama (Arifin, Kulsum, \& Mutiarawati, 2020), dan pelajar yang tinggal di asrama memiliki kompetensi yang lebih baik dari pelajar yang di luar asrama (Wahidah, 2020).

Berbagai program berbahasa diterapkan di pondok- pondok pesantren di Indonesia. Ada banyak pondok pesantren yang menerapkan bahasa Arab sebagai bahasa sehari-hari dan juga sebagai bahasa pengantar dalam pembelajaran sehingga santri memiliki jiwa eksploratif dalam pemerolehan bahasa Arab (Ismanto, 2017). Kegiatan kebahasaan yang dilakukan seperti percakapan harian yang didukung dengan pemberian mufrodat harian dan hapalan, dilengkapi dengan kamus yang selalu dibawa dan fasilitas yang memadai, program terjadwal seperti latihan pidato, kursus intensif bagi santri baru (Maghfiroh, 2016). 
Di antara pondok pesantren juga ada yang berupaya meningkatkan keterampilan berbicara bahasa Arab dengan melaksanakan program pembinaan keterampilan berbicara bahasa Arab bagi para santri/santriwati berupa workshop dan kemudian pendampingan, sehingga mereka memiliki motivasi dan keberanian untuk mencoba berbicara dengan bahasa Arab (Maujud, 2017). Ada juga pondok pesantren yang menekankan mata pelajaran berbahasa Arab pada kurikulumnya dan seluruh materi pelajaran agama menggunakan bahasa Arab sebagai bahasa pengantar dalam proses pembelajaran sehingga mendorong terciptanya lingkungan yang dapat meningkatkan keterampilan berbicara bahasa Arab (Kurniawati, 2016; Rasyidi, 2020).

Di sebuah pondok pesantren putri di Kalimantan Selatan diterapkan juga komunikasi berbahasa Arab. Santriwati yang sebelumnya belum mampu berkomunikasi dalam bahasa Arab akhirnya mampu menerapkannya dalam kehidupan sehari-hari termasuk ungkapan bahasa. Penelitian tentang penerapan bahasa Arab dalam kehidupan sehari-hari di pondok pesantren memang sudah diteliti, namun setiap pondok pesantren memiliki sistem masing-masing dalam menerapkan percakapan berbahasa Arab, sebagaimana dikatakan Syahid (2015) bahwa pemerolehan bahasa kedua bisa terjadi sama seperti pemerolehan bahasa pertama dan bisa juga melalui belajar. Setiap individu dan kelompok memiliki cara masing-masing dalam meningkatkan kemampuan berbicara bahasa asing mereka (Syahid, 2015).

Dalam keseharian santriwati kemungkinan juga ada ungkapan dalam bahasa Indonesia atau daerah yang belum tentu ada dalam bahasa Arab karena perbedaan budaya bahasa-bahasa tersebut sebagaimana yang dikatakan Devianty (2017) bahwa bahasa dipengaruhi oleh cara berpikir masyarakat penuturnya, sehingga segala hal yang ada dalam kebudayaan akan tercermin dalam bahasa mereka. Selain itu lebih khusus lagi penelitian tentang pemerolehan ungkapan bahasa Arab di pondok pesantren masih jarang ditemukan. Penelitian ini bertujuan untuk mendeskripsikan bagaimana proses pemerolehan ungkapan-ungkapan bahasa Arab santriwati baru dan apa saja jenis ungkapan bahasa Arab tersebut (Devianty, 2017). 


\section{METODE}

Penelitian deskriptif kualitatif ini dilaksanakan di sebuah pondok pesantren putri di kota Banjarbaru Kalimantan Selatan Indonesia. Penelitian ini meneliti proses pemerolehan ungkapan-ungkapan bahasa Arab santriwati dan jenis ungkapan-ungkapan bahasa Arab tersebut yang digali dari 15 (lima belas) orang santriwati sebagai subjek penelitian melalui teknik wawancara, observasi dan dokumentasi.

Teknik wawancara dilakukan untuk menggali data tentang proses pemerolehan ungkapan-ungkapan bahasa Arab bagi santriwati baru. Teknik observasi dilakukan untuk mengamati berbagai kegiatan penggunaan bahasa Arab santriwati baru dalam kehidupan sehari-hari di lingkungan pondok pesantren serta menyimak percakapan mereka baik untuk data tentang pemerolehan ungkapan bahasa Arab maupun untuk mengklasifikasikan jenis ungkapan bahasa Arab yang digunakan di lingkungan pondok pesantren putri tersebut. Teknik dokumentasi digunakan untuk melihat dokumen terkait pemerolehan ungkapan bahasa Arab seperti media belajar. Diperlukan pula data dari informan lainnya seperti santriwati senior, dan ustadzah.

Pemeriksaan keabsahan data dilakukan dengan menggunakan triangulasi data dengan memanfaatkan sesuatu yang lain di luar data tersebut untuk mengecek atau membandingkan dengan data tersebut. Data dianalisis sejak mulai terkumpul sampai selesai pengumpulan data. Analisis ini dilakukan dengan tahapan pengumpulan data, reduksi data, penyajian data dan penarikan kesimpulan (Miles \& Huberman, 2002).

\section{HASIL DAN PEMBAHASAN}

\section{Proses Pemerolehan Ungkapan-ungkapan Bahasa Arab Bagi Santriwati Baru}

Sebuah Pondok Pesantren Putri di Kalimantan Selatan menerapkan bahasa Arab dan bahasa Inggris dalam berkomunikasi sehari-hari. Dalam proses pemerolehan bahasa termasuk ungkapan bahasa Arab, santriwati baru di pondok pesantren tersebut memiliki kemampuan dasar yang berbeda. Ada yang belum bisa sama sekali, tetapi ada juga yang sudah memiliki sedikit pengetahuan tentang bahasa Arab sesuai latar belakang pendidikan masing-masing sebelum memasuki pondok pesantren. Karena pada umumnya semua santriwati baru belum bisa 
berbahasa asing, maka pihak pondok pesantren tersebut memberikan waktu enam bulan bagi santriwati baru dalam mengupayakan penguasaan bahasa Arab dan Inggris melalui berbagai cara dalam pemerolehan bahasa.

Dari 15 (lima belas) orang santriwati yang diteliti melalui wawancara dan observasi diketahui bahwa santriwati begitu memasuki asrama masih diperbolehkan menggunakan bahasa Indonesia dalam berkomunikasi, namun tidak diperbolehkan menggunakan bahasa daerah. Selama itu santriwati berusaha menguasai bahasa Arab melalui berbagai upaya masing-masing. Selanjutnya setelah enam bulan santriwati baru diwajibkan berbahasa Arab atau bahasa Inggris sesuai dengan jadwal roling dalam tiap minggu. Dalam kurun waktu yang sudah ditentukan, santriwati diperbolehkan berbahasa Indonesia namun tetap berusaha memperoleh bahasa Arab termasuk ungkapannya. Waktu yang diberikan ini dimaksudkan agar santriwati memiliki persiapan untuk memiliki dan meningkatkan kemampuan berbahasa Arab.

Dalam pergaulan sehari-hari, santriwati baru mendengarkan percakapan dalam bahasa Arab di lingkungan pondok pesantren baik dari ustadzah maupun kakak tingkatnya di mana saja berada seperti di kamar, asrama, kamar mandi, dapur, ruang makan, masjid, kelas, lapangan olah raga halaman sekolah dan sebagainya. Apa yang didengar oleh santriwati mereka ingat dan ada juga yang mecatatnya supaya tidak lupa. Mereka memiliki semangat agar mampu berbahasa Arab dengan baik. Berbagai upaya dilakukan oleh santriwati baru dalam upaya pemerolehan bahasa dan ungkapan-ungkapannya, kemudian mereka mencobanya dan sampai akhirnya mereka menerapkannya dalam kehidupan sehari-hari.

Menyimak percakapan berbahasa Arab dari senior di lingkungan pondok pesantren merupakan upaya umum santriwati dalam memiliki kemampuan berkomunikasi dalam bahasa Arab. Dengan begitu mereka akan mengingat bahasa termasuk ungkapan yang sering diucapkan dan sesuai konteks. Semangat merupakan kekuatan untuk meningkatkan kemampuan apa saja sebagai jalan untuk mencapai harapan yang diinginkan. Semangat tentu saja disertai dengan usaha keras. Dengan demikian santriwati akan terbiasa menyimak dan berupaya mempraktikkan bahasa Arab. Upaya lain adalah meniru dan mencatat apa yang didengar, sebagai salah satu cara belajar sehingga dengan mempraktikkan langsung bahasa Arab tidak mudah terlupa. Penerapan berbahasa Arab dalam kehidupan 
sehari-hari baik di lingkungan formal maupun informal ini merupakan upaya dalam rangka meningkatkan kemampuan santriwati berkomunikasi dalam bahasa Arab. Dalam pemerolehan bahasa Arab, santriwati memperolehnya di antaranya dari menyimak bahasa Arab orang sekitarnya, Hal ini sesuai dengan yang disebutkan Syahid (2015) bahwa proses pemerolehan bahasa kedua atau asing bisa juga seperti proses pemerolehan bahasa pertama (Syahid, 2015).

Selain memperoleh ungkapan bahasa Arab dari mendengarkan seniornya, santriwati juga memperoleh ungkapan bahasa Arab melalui menyimak ucapan pengajar pada saat pembelajaran di kelas. Penggunaan bahasa Arab diterapkan pengajar di kelas untuk mata pelajaran bahasa Arab dan cabangnya serta pelajaran agama lainnya kecuali mata pelajaran umum yang pengajarnya tidak memiliki kemampuan bahasa Arab atau pengajar dari luar pondok pesantren. Setiap hari santriwati terbiasa mendengarkan, memahami dan pada akhirnya mampu berkomunikasi dalam bahasa Arab. Dengan demikian santriwati baru memperoleh ungkapan bahasa Arab melalui menyimak percakapan di lingkungan tempat tinggal dan tempat umum serta di lingkungan formal yang diterapkan komunikasi berbahasa Arab.

Pembelajaran pada suatu mata pelajaran dengan menggunakan bahasa Arab sebagai bahasa pengantar dalam berkomunikasi memiliki dua keuntungan yakni memperoleh pengetahuan dan sekaligus juga meningkatkan kemampuan bahasa Arab. Hal ini sesuai dengan hasil penelitian Hunt, Somer dan kawan-kawan bahwa pembelajaran konten melalui bahasa asing sekaligus mempelajari bahasa tersebut melalui konten seperti hal ini sangat menyenangkan bagi pelajar. Pelajar merasa memiliki kemajuan dan menyadari adanya manfaat praktis bagi kehidupan dan karir masa depan mereka (Hunt, 2011; Somers \& Llinares, 2018).

Bagi yang ingin meningkatkan kemampuan berbahasa Arab, kegiatan lingkungan bahasa ini merupakan sebuah peluang untuk lebih mampu dan menguasai bahasa Arab, karena terjadinya komunikasi antar personil yang ada dan akan semakin banyak ungkapan yang diperoleh karena banyaknya pengetahuan yang didapat dari banyak orang. Sebagaimana yang disebutkan Nurul Hidayah bahwa lingkungan yang dibentuk oleh pengajar dan senior merupakan sebuah peluang yang bisa digunakan bersama, sehingga pelajar mendapatkan ilmu bahasa dan mampu menerapkannya dengan baik (Hidayah, 2019). Kapoh menyebutkan 
bahwa lingkungan sangat berpengaruh dalam proses pemerolehan bahasa kedua (Kapoh, 2010). Pembelajaran bahasa Arab berbasis lingkungan lebih efektif dan berpengaruh terhadap kemahiran berbahasa Arab. Sebab kemampuan berbahasa tidak hanya ditentukan oleh LAD (Language Acquisition Device) melainkan sangat dipengaruhi oleh lingkungan di mana seseorang tersebut tinggal (Habibah, 2016).

Semangat santriwati baru dalam mengejar kemampuan berbahasa Arab dalam lingkungan bahasa yang diterapkan bersama akan membuat santriwati memiliki rasa percaya diri. Ustadzah dan seniorpun akan merasa senang karena merasa berguna bagi juniornya. Sejalan dengan hasil penelitian Clyne, Marisa Cordella, Doris Schiipbach dan Brigid Maher (2013) bahwa pelajar akan memiliki rasa percaya diri dan memiliki motivasi dan empati terhadap lintas budaya dan generasi. Senior memahami juniornya dengan bagi dan merasa puas karena merasa berguna bagi lingkungannya, Hubungan senior dan junior dan budaya berkembang atas dasar bahasa bersama (Clyne, Cordella, Schupbach, \& Brigid, 2013).

Dalam upaya mendukung program berbicara bahasa Arab, pondok pesantren putri ini melalui pengajarnya memberikan ungkapan bahasa Arab berupa media kartu ungkapan bahasa Arab bagi santriwati yang selanjutnya santriwati mengingat, menghapal dan menerapkannya dalam mehidupan sehari-hari. Bagi santriwati baru yang masih merasa kesulitan dalam belajar bahasa Arab terus mendapat dorongan dari teman-temannya sehingga tetap bersemangat dalam belajar. Pondok pesantren putri ini membuat program berbahasa asing dengan mewajibkan santriwati berkomunikasi dalam bahasa tersebut secara bergantian, dan pondok pesantren tersebut memberikan pula cara mudah dalam melaksanakannya berupa menyiapkan kartu ungkapan bahasa Arab untuk diingat dan dihapal santriwati.

Menguasai banyak kosa kata dan kalimat tertentu yang berkaitan dengan situasi merupakan salah satu hal yang penting dalam kemampuan berbicara bahasa Arab, karena mampu berbicara berarti mampu mengutarakan pikiran dan perasaannya secara lisan dan tepat dalam menggunakan kosa kata dan kalimat. Semakin banyak siswa memiliki kosa kata dan menguasai qawaid, semakin berani dia berbicara dalam bahasa Arab (Syamaun, 2016).

Adanya saling mendukung dan memberi support sangatlah penting dalam hidup di pondok pesantren, karena santriwati datang dan tinggal di sana tanpa adanya keluarga. Teman-temannyalah yang membantu jika ada kesulitan seperti 
layaknya saudara. Pertolongan itu berupa apa saja termasuk memberikan dukungan dan motivasi terhadap kawan-kawan yang mengalami kesulitan dalam belajar.

Proses pemerolehan bahasa juga bisa terjadi karena sering mendapat hukuman berupa membersihkan suatu tempat sambil menghapal. Hukuman diberikan karena adanya pelanggaran yakni tidak berbahasa Arab sesuai dengan peraturan pondok pesantren atau menambahkan imbuhan bahasa lain ke dalam bahasa Arab.

Pemerolehan bahasa termasuk ungkapan bahasa Arab bisa terjadi karena mendapat hukuman akibat kesalahan dalam berbicara bahasa Arab di pondok pesantren tersebut. Setiap tempat memiliki budaya masing-masing. Dalam budaya ada bahasa yang sesuai dengan budayanya. Ada faktor paksaan yang positif di sini. Dengan terjadinya kesalahan yang harus diperbaiki dan memanfaatkan kesalahan itu dengan membersihkan lingkungan akan mendapatkan dua manfaat, yakni meningkatnya kemampuan berbahasa Arab karena sering menghapal dan bersihnya lingkungan. Kesalahan dalam belajar bahasa asing sangatlah wajar, sebagaimana yang dikatakan oleh Sri Wahyuni (2015) bahwa kemampuan pelajar dalam berbicara bahasa kedua dapat dipengaruhi oleh bahasa pertamanya (Wahyuni, 2015). Nurul Hidayat (2019) juga menyebutkan bahwa tantangan pemerolehan bahasa Arab sebagai bahasa kedua di antaranya adanya perbedaan kaidah kebahasaan antara bahasa Arab dengan bahasa Indonesia. dengan bahasa Indonesia yang membuat pembelajar merasa kesulitan. Selain itu juga pengaruh pengalaman bahasa pertama yang mengakibatkan adanya bahasa Indonesia yang diarabkan atau proses bahasa antara. Untuk itu pembelajar harus mengatasi dan mempelajari kesalahannya dalam berbahasa (Hidayah, 2019).

Selain itu pemerolehan ungkapan bahasa bisa dari belajar sendiri maupun kelompok. Belajar sendiri bisa dengan mencari materi di buku bahasa Arab. Untuk belajar kelompok dilakukan pada malam hari di luar asrama dengan cara membagi tugas kepada anggota kelompok mencari ungkapan yang belum diketahui bahasa Arabnya.

Pemerolehan ungkapan bahasa tidak datang dengan sendirinya, tetapi melalui proses di antaranya dengan belajar baik secara mandiri maupun kelompok. Kegiatan belajar dilakukan karena adanya kekurangan yakni tidak diketahuinya ungkapan-ungkapan dalam bahasa Arab. Belajar mandiri berupa menggali 
ungkapan apa saja yang tidak diketahui khususnya diri pribadi, sementara belajar kelompok dapat mencarikan ungkapan bahasa Arab apa yang tidak diketahui hampir semua santriwati dalam kelompok serta saling berbagi pengalaman. Hal ini sesuai dengan apa yang dikatakan Syahid bahwa pemerolehan bahasa kedua juga bisa terjadi melalui proses belajar. Model pemerolehan bahasa kedua dengan model stimulus-respon merujuk pada teori bahwa segala sesuatu dibutuhkan penguatan, pengulangan serta Latihan. Potensi keberhasilan belajar bahasa asing lebih banyak terletak pada diri pembelajar itu sendiri. Pembelajar tidak bisa hanya mengandalkan pengajar dan kecerdasan dirinya saja, melainkan juga harus mempunyai strategi belajar (Isyam, 2011).

Dengan demikian, pemerolehan ungkapan bahasa Arab di pondok pesantren putri melalui menyimak percakapan dalam bahasa Arab oleh santriwati dan ustadzah yang memang sudah mampu dan mahir dalam berbicara. Pemerolehan ungkapan bahasa Arab juga didapatkan dengan cara belajar baik mandiri maupun kelompok dengan menggunakan media kartu ungkapan yang sudah disediakan dan juga buku bahasa Arab.

\section{Jenis Ungkapan Bahasa Arab di Pondok Pesantren Putri}

Jenis ungkapan bahasa Arab diperoleh santriwati di sebuah pondok pesantren putri berdasar tempat di lingkungan sekitar pondok pesantren tersebut. Di antaranya mereka memperoleh ungkapan-ungkapan tersebut di kamar, asrama, kamar mandi, dapur atau ruang makan, koperasi, masjid, kelas, halaman pondok pesantren dan taman. Ungkapan yang terdapat pada lingkungan kamar seperti himbauan menjaga kebersihan lingkungan, himbauan merapikan tempat tidur dan pakaian yang bergantungan, meletakkan sesuatu pada tempatnya, himbauan tidak begadang, himbauan untuk selalu menjaga kesehatan, membangunkan kawankawan dan mengingatkan waktu sholat subuh, himbauan agar tidak telat mandi, menaruh alat mandi pada tempatnya dan lain sebagainya.

Ungkapan yang terdapat di lingkungan asrama seperti himbauan tidak telat ke kelas, ajakan menuju kelas bersama, ajakan menuju masjid untuk shalat berjama'ah atau kegiatan rutin keagamaan, mengingatkan giliran bertugas kebersihan asrama, ajakan menuju tempat gotong royong dan lainnya.

Ungkapan yang terdapat di kamar mandi dan sekitarnya seperti himbauan untuk selalu menjaga kebersihan, ungkapan mengingatkan tidak terlalu lama mandi, 
himbauan antri menunggu giliran memakai kamar mandi, tidak menggunakan terlalu banyak air atau mubazir dan lain sebagainya..

Ungkapan yang terdapat di lingkungan dapur atau ruang makan seperti ajakan antri menunggu giliran menerima menu, ajakan makan bersama, makan jangan terburu-buru, menjaga kebersihan lingkungan dan lain sebagainya.

Ungkapan yang terdapat di lingkungan koperasi seperti ajakan untuk berbelanja keperluan sehari-hari, ajakan makan bersama di koperasi, ajakan minum bersama, ajakan untuk istirahat, ajakan melihat barang-barang belanjaan yang baru datang dan lain sebagainya.

Ungkapan yang terdapat pada lingkungan masjid seperti mengingatkan waktu shalat, himbauan mengisi sajadah di depan atau tempat yang kosong, himbauan meratakan shaf, meletakkan al-Quran pada tempatnya, ajakan tadarus bersama, larangan bercakap-cakap dan lain sebagainya.

Ungkapan yang terdapat di kelas, halaman dan taman pondok pesantren seperti sapaan, menanyakan kabar, memberi semangat belajar, mendengarkan penjelasan dan memperhatikan guru, meletakkan alas kaki pada tempatnya, himbauan menjaga kebersihan lingkungan, ajakan meembersihkan taman, ajakan berkebun bunga, ajakan untuk bersantai, ajakan belajar bersama, mengajak olahraga dan lainnya. Ungkapan yang terdapat pada ruang tamu seperti pengumuman, panggilan kepada santriwati yang kedatangan tamu dan lain sebagainya.

Dari ungkapan-ungkapan bahasa Arab yang diperoleh dan digunakan di lingkungan pondok pesantren putri yang disebutkan di atas, ada tiga jenis ungkapan bahasa Arab yakni ungkapan berupa himbauan, larangan dan ajakan. Ungkapan yang diperoleh santriwati baru dan diterapkan dalam lingkungan berbahasa Arab hanya sebatas tempat di lingkungan pondok pesantren yang terdiri dari tempat tinggal, tempat beribadah dan kegiatan keagamaan serta tempat belajar formal dan tinggal dalam lingkungan tersebut bersama orang yang sama dalam menggunakan bahasa Arab. Mereka akan mampu dalam berbahasa Arab dengan kosa kata dan ungkapan sebatas tiga tempat tersebut. Namun tidak menutup kemungkinan kosa kata yang digunakan di tiga tempat tersebut akan bisa diterapkan di luar itu, dan ungkapan yang ada pada lingkungan mereka juga kemungkinan belum tentu diterapkan di tempat lain, Misalnya ungkapan yang ada di kamar di sebuah asrama, 
belum tentu digunakan di tempat lain, seperti himbauan untuk selalu rapikan kamar, makan bersama, pergi ke kelas bersama, pergi ke masjid bersama, ajakan memasak dan makan bersama. Rasa persaudaraan yang erat membuat adanya suatu kebiasaan di tempat tersebut yang tidak ada pada tempat lain.

Santriwati baru dan senior memiliki kebiasaan keseharian di lingkungan pondok pesantren putri dan di antaranya tercermin dalam bahasa dan ungkapan mereka dalam bahasa Arab. Hal ini sebagaimana yang dikatakan oleh Devianti bahwa bahasa dipengaruhi oleh bagaimana masyarakat penuturnya berpikir dan apa yang ada dalam kebudayaan mereka akan tercermin dari bahasanya (Devianty, 2017). Mujib mengatakan bahwa hubungan antara budaya dan bahasa di sini bersifat subordinatif yakni dinamika budaya mempengaruhi dinamika Bahasa (Mujib, 2009). Salah satu fungsi bahasa adalah untuk mengidentifikasi suatu kelompok. Ini berarti dengan bahasa dapat diketahui identitas seseorang baik individu maupun kelompok (Santoso, 2006).

\section{SIMPULAN}

Pondok pesantren putri mewajibkan santriwati berbahasa Arab dalam kehidupan sehari-hari dan menerapkannya dalam lingkungan formal maupun informal. Bagi santriwati baru yang belum dan kurang mampu berbicara dalam bahasa Arab diberi waktu selama enam bulan untuk belajar berbicara bahasa Arab dengan berbagai cara. Pemerolehan bahasa Arab termasuk ungkapannya didapatkan melalui menyimak percakapan santriwati senior dan ustadzah dalam kehidupan sehari-hari di lingkungan pondok pesantren putri, menyimak dan memperhatikan penjelasan ustadz dan ustadzah yang mengajar di kelas dengan menggunakan bahasa Arab pada mata pelajaran bahasa Arab dan cabangnya serta mata pelajaran agama, penggunaan strategi belajar dengan cara mengingat, mencatat, dan atau menghapal apa yang didengar dan menerapkannya, menghapal ungkapan yang diberikan ustadzah melalui kartu ungkapan, menghapal saat mendapat hukuman kebersihan lingkungan, selalu memiliki semangat untuk mampu berbahasa Arab dengan baik dan mendapat dukungan dari kawan-kawan, belajar kelompok dengan membagi tugas mencari ungkapan bahasa. Jenis ungkapan bahasa Arab yang diperoleh adalah ungkapan yang digunakan di tempat-tempat di lingkungan pondok pesantren putri tersebut baik lingkungan formal maupun informal berupa himbauan, ajakan dan larangan. Implikasi dari penelitian ini adalah 
keterampilan berbahasa asing akan mudah dikuasai dengan semangat belajar, strategi belajar baik individual maupun kelompok serta dibantu media pembelajaran.

\section{DAFTAR PUSTAKA}

Arifin, R. A., Kulsum, E. M., \& Mutiarawati, R. (2020). Persepsi Siswa Tentang Lingkungan Belajar Bahasa dan Motivasi dalam Meningkatkan Keterampilan Bahasa. Jurnal Perspektif, 4(2), 135-143.

Clyne, M., Cordella, M., Schupbach, D., \& Brigid, M. (2013). Connecting younger second-language learners and older bilinguals: Interconnectedness and social inclusion. International Journal of Multilingualism, 10(4), 375-393. https://doi.org/https://doi.org/10.1080/14790718.2013.832120

Davik, D. (2019). Urgensi Biah Arabiyah dalam Meningkatkan Keterampilan Berbicara Bahasa Arab Siswa. Jurnal TAUJIH, 12(1).

Devianty, R. (2017). Bahasa Sebagai Cermin Kebudayaan. JURNAL TARBIYAH, 24(2). https://doi.org/https://doi.org/10.30829/tar.v24i2.167

Habibah, N. (2016). Lingkungan Artifisial dalam Pembelajaran Bahasa Arab. Arabiyat : Jurnal Pendidikan Bahasa Arab dan Kebahasaaraban, 3(2), 173-196. https://doi.org/https://doi.org/10.15408/a.v3i2.4038

Hamidah, H. (2019). Arabic Language: Between Learning Necessity and Responsibility (ar). Al-Ta'rib : Jurnal Ilmiah Program Studi Pendidikan Bahasa Arab IAIN Palangka Raya, 7(1), 35-44. https://doi.org/https://doi.org/10.23971/altarib.v7i1.1472

Hermawan, A. (2011). Metodologi Pembelajaran Bahasa Arab. Bandung: Remaja Rosdakarya.

Hidayah, N. (2019). Peluang dan Tantangan Pemerolehan Bahasa Arab Sebagai Bahasa Kedua (Kajian Psikolinguistik pada Pembelajaran Bahasa Arab). Taqdir, 5(2), 65-76. https://doi.org/https://doi.org/10.19109/taqdir.v5i2.4922

Hidayat, A. (2012). Biah Lughawiyah (Lingkungan Berbahasa) dan Pemerolehan Bahasa (Tinjauan tentang Urgensi Lingkungan Berbahasa dalam Pemerolehan Bahasa). Jurnal Pemikiran Islam, https://doi.org/http://dx.doi.org/10.24014/an-nida.v37i1.311

Hunt, M. (2011). Learners' perceptions of their experiences of learning subject content through a foreign language. 63(3), 365-378. https://doi.org/https://doi.org/10.1080/00131911.2011.571765

Ismanto, A. A. (2017). MA'HAD Al-JAMI'AH (Model Alternatif Pembelajaran Bahasa Arab di Perguruan Tinggi Islam). Misykah : Jurnal Pemikiran Dan Studi Islam, 1(1), 60-73.

Isyam, Am. (2011). Strategi-strategi Belajar Bahasa Asing. Lingua Didaktika: Jurnal Bahasa Dan Pembelajaran Bahasa, 4(2), 86-95. https://doi.org/https://doi.org/10.24036/ld.v4i2.1259

Kapoh, R. J. (2010). Beberapa Faktor Yang Berpengaruh Dalam Perolehan Bahasa. Jurnal Interlingua, 4, 9. 
Kurniawati, I. (2016). Manajemen Pesantren untuk Meningkatkan Keterampilan Berbicara Bahasa Arab di Pondok Pesantren Diniyyah Pasia Kabupaten Agama. al-fikrah: Jurnal Manajemen Pendidikan, 4(2). https://doi.org/https://doi.org/10.31958/jaf.v4i2.418

Maghfiroh, A. (2016). From Daily to Fluency: Melejitkan Kemampuan Bahasa Asing dengan Aktifitas Bahasa Harian. Jurnal Dimensi Pendidikan dan Pembelajaran, 3(2), 49-56. https://doi.org/https://doi.org/10.24269/dpp.v3i2.85

Maujud, F. (2017). Pembinaan Keterampilan Berbicara Bahasa Arab (Mahart alKalam) Santri dan Santriwati di Pondok Pesantren Darul Hikmah Pagutan Karang Genteng Kota Mataram. El-Tsaqafah : Jurnal Jurusan PBA, 16(2), 127139. https://doi.org/https://doi.org/10.20414/tsaqafah.v16i2.447

Miles, M. B., \& Huberman, A. M. (2002). The Qualitative Researcher's Companion.

Mujib, A. (2009). Hubungan Bahasa dan Kebudayaan, (Perspektif Sosiolinguistik). Adabiyyāt: Jurnal Bahasa dan Sastra, 8(1), 141-154. https://doi.org/https://doi.org/10.14421/ajbs.2009.08107

Muradi, A. (2014). Pendekatan Komunikatif dalam Pembelajaran Bahasa Arab. Arabiyat: Jurnal Pendidikan Bahasa Arab Dan Kebahasaaraban, 1(1), 29-48. https://doi.org/https://doi.org/10.15408/a.v1i1.1129

Purba, A. (2013). Peranan Lingkungan Bahasa dalam Pemerolehan Bahasa Kedua. Pena : Jurnal Pendidikan Bahasa Dan Sastra, 2(2).

Rasyidi, Z. Z. (2020). embelajaran Qawaid: Perspektif Teori Kognitif pada Pondok Pesantren Raudhatut Thalibin Kalimantan Selatan. Al-Ta'rib: Jurnal Ilmiah Program Studi Pendidikan Bahasa Arab IAIN Palangka Raya, 8(1), 103-116. https://doi.org/https://doi.org/10.23971/altarib.v8i1.1865

Santoso, B. (2006). Bahasa dan Identitas Budaya. Sabda: Jurnal Kajian Kebudayaan, 1(1), 44-49. https://doi.org/https://doi.org/10.14710/sabda.1.1.44-49

Sentosa, A. R., \& Apriliani, N. (2020). Pemerolehan Bahasa pada Anak Usia Dini (Kajian Psikolinguistik). Prosiding Seminar Nasional Pendidikan, 1-7.

Somers, T., \& Llinares, A. (2018). Students' motivation for content and language integrated learning and the role of programme intensity. International Journal of Bilingual Education and Bilingualism, 1-16. https://doi.org/https://doi.org/10.1080/13670050.2018.1517722

Suardi, I. P., Ramadhan, S., \& Asri, Y. (2019). Pemerolehan Bahasa Pertama pada Anak Usia Dini. Jurnal Obsesi : Jurnal Pendidikan Anak Usia Dini, 3(1), 265-273. https://doi.org/https://doi.org/10.31004/obsesi.v3i1.160

Sundari, H. (2017). Model-model Pembelajaran dan Pemerolehan Bahasa $\begin{array}{lll}\text { Kedua/Asing. } & \text { Pujangga, } & 12 .\end{array}$ https://doi.org/https://doi.org/10.47313/pujangga.v1i2.321

Syahid, Ah. H. (2015). Bahasa Arab Sebagai Bahasa Kedua (Kajian Teoritis Pemerolehan Bahasa Arab pada Siswa Non-Native). Arabiyat: Jurnal Pendidikan Bahasa Arab dan Kebahasaaraban2, 2(1), 86-97. https://doi.org/https://doi.org/10.15408/a.v2i1.1797

Syamaun, N. (2016). Pembelajaran Maharah al-Kalam untuk Meningkatan 
Keterampilan Berbicara Mahasiswa Program Studi Pendidikan Bahasa Arab Fakultas Tarbiyah dan Keguruan. لسـنانL (LISANUNA): Jurnal Ilmu Bahasa Arab dan Pembelajarannya, 4(2), 343-359. https://doi.org/https://doi.org/10.22373/l.v4i2.852

Tarigan, H. G. (2011). Pengajaran pemerolehan bahasa. Bandung: Angkasa.

Unsi, B. T. (2015). Kemahiran Berbicara Bahasa Arab melalui Penciptaan Lingkungan Bahasa. Tafáqquh: Jurnal Penelitian Dan Kajian Keislaman, 3(1), 123-141. https://doi.org/https://doi.org/10.52431/tafaqquh.v3i1.42

Vetiana, G. V. (2019). The Role of the Center for Language Improvement in Enhanching Speaking Skills of The Class One of The Modern Islamic Boarding School Darussalam Gontor at The Girls' Second Campuss (ar). Al-Ta'rib : Jurnal Ilmiah Program Studi Pendidikan Bahasa Arab IAIN Palangka Raya, 7(2), 111120. https://doi.org/https://doi.org/10.23971/altarib.v7i2.1518

Wahidah, B. Y. K. (2020). No Title. JUPE: Jurnal Pendidikan Mandala, 5(5). https://doi.org/https://doi.org/10.36312/jupe.v5i5.1296

Wahyuni, S. (2015). engaruh Bahasa Pertama Terhadap Bahasa Kedua Dalam Kemampuan Berbicara Untuk Siswa Kelas IX Pesantren Modern Al-Falah Abu Lam-U Kabupaten Aceh Besar. Visipena, 6(2), 52-67. https://doi.org/https://doi.org/10.46244/visipena.v6i2.365 